\title{
The Tools of the Digital Economy: Strategic Aspects of Blockchain Technology Application
}

\author{
Daria Vladimirskaya \\ Institute of international programs \\ Saint-Petersburg University of \\ Management Technologies and \\ Economy \\ Saint-Petersburg, Russia \\ belyeva_dasha@mail.ru
}

\author{
Elena Zvyagina \\ Institute of international programs \\ Saint-Petersburg University of \\ Management Technologies and \\ Economy \\ Saint-Petersburg, Russia \\ zvyaginaem@yandex.ru
}

\author{
Kazbek Koraev \\ Cathedra of population and territories \\ protection \\ Saint Petersburg University of State \\ Fire Service of Emercom of Russia \\ Saint-Petersburg, Russia \\ Koraev.kaz@yandex.ru
}

\begin{abstract}
Today, the economic development of countries directly depends on the speed of transition to the digital economy. The ability to quickly process and store arrays of digital data increases the efficiency of various types of production from technology development to the delivery of goods and services. One of the tools of the digital economy, facilitating economic growth and increasing the competitiveness of the country in the global market is blockchain technology. The aim of the study was to analyze the level of implementation of blockchain technology in various infrastructural components of an economically developed state, affecting the set of economic and social conditions that ensure the integrated development of national production. The degree of development of this technology in Russia was also assessed. The obtained results allowed the authors to assess the degree of implementation of blockchain technology in various levels of infrastructure development both in Russia and abroad.
\end{abstract}

Keywords: blockchain, digital economy, strategy, information infrastructure

\section{INTRODUCTION}

According to May Decrees of the President of the Russian Federation Vladimir Putin, the national program "Digital Economy of the Russian Federation" should be implemented in the country until 2024, which in turn focuses on the Strategyfor the Development of the Information Society in the Russian Federation for 20172030. In the Decree № 203 "On the strategy of information society development in the Russian Federation for the years 2017-2030" the first official definition of the digital economy as economic activities, which is a key production factor are the data in digital form, the processing of large volumes and using the results of analysis compared with traditional forms of management allow to increase significantly the efficiency of various types of production, technologies, equipment, storage, sales, delivery of goods and services was done. The main goal of the program "Digital economy of the Russian Federation" is not just the using of information technologies in all sectors, namely the development of social and business climate in Russia, i.e. the development of the digital economy for Russia is a strategically important issue that determines its competitiveness on the world stage $[1,2]$.
The National project includes the following Federal projects:

- Regulatory regulation of the digital environments;

- Information infrastructure;

- Manpower for the digital economy;

- Information security;

- Digital technologies;

- Digital state administration.

The main digital technologies in the program are the following:

- big data;

- Neurotechnology and artificial intellect;

- distributed registry systems (blockchain);

- quantum technologies;

- new production technologies;

- industrial Internet;

- robotics and sensor components;

- wireless communication technologies;

- the technologies of virtual and augmented realities.

One of the main technologies that should become part of the digital economy of Russia and the driver of its development, of course, is blockchain. The technology of distributed registries is still young and unclear to many, but the benefits of its application have been thought about both at the state level and in the largest corporations.

\section{METHODS}

Within the framework of this study, the authors used general scientific methods of cognition that allow analyzing the degree of implementation of blockchain technology as an element of the digital economy in the entrepreneurial component of Russian and foreign companies. The depth of the study is 2017-2019. It is especially relevant for Russian companies, in which these technologies are just beginning to be introduced and approved at the legislative level. The 
research materials were mainly scientific articles, materials of the annual international congresses on the use of blockchain technologies in the global community Blokchein Life (2018-2019), materials of the OECD (Organization for Economic Cooperation and Development). The selection of foreign companies was carried out randomly on the basis of openness and availability of information. For Russian companies, the Unified state register of legal entities was used, according to which about 20 companies were registered [3-5], the name of which mentions the term "blockchain". However, the analysis was carried out in the context of the formation of blockchain technologies in Russia and included giant companies-the founders of the development of this technology.

\section{RESULTS}

Blockchain is a distributed database, a so-called network, in which all actions are recorded. This database stores data on time, date, participants of operations, transaction amounts, etc. Blockchain works on the basis of mathematical algorithms. All records that fall into this system are combined into blocks, which in turn are cryptographically arranged in a chronological chain. This process is performed and supported by a large number of computers running on the same network. If the calculations of all servers in the system produce the same result, the block is assigned a unique encrypted signature called a hash. New blocks are automatically added to the end of the chain and closed. After their formation, they can no longer be changed, because the information contained in the formed blocks is sent by the system to all servers of the network [6].

Each separate part of the network (each user of the network) has copies of all records of the blockchain since its launch. This makes the information contained in the blockchain unchanged, since it is impossible to change the information on several servers at the same time. If someone tries to cheat and change the information in one of the already closed blocks, all users will know about it, because the encrypted hash of the unchanged blocks will remain the same and the system will immediately give an error. With this feature, the blockchain can easily identify the block in which the information was changed.

Blockchain has a number of other, no less important features:

- Immutability of data (their integrity);
- Trust for all members of the network;

- Decentralized system of work;

- Openness (transparency);

- Security against hacking;

- Distributed information storage;

- The exclusion of additional intermediaries;

- Availability of smart contracts.

Of course, due to its novelty in the implementation of this mechanism, there are a number of shortcomings, the solution of which is given a lot of resources. The main ones include:

- Uncertain legal status;

- Lack of awareness of people;

- Lack of examples of full transition of large organizations to blockchain;

- Open access of all participants to any information;

- Errors in writing software;

- Too "heavy" amount of information;

- Increased excitement around new technology;

- Use as a marketing tool;

- Speed limit (depending on business processes).

However, even despite all the disadvantages of a distributed database, programmers, governmental bodies and major companies in some countries of the world are still pursuing an active policy to introduce this technology into the lives of both people and companies themselves. For a clearer understanding of this technology, here is an example: imagine a digital case history: each record is a separate block of this technology. This entry has a label: date and time of entry. Initially, it is considered mandatory to ban the modification of records retroactively, because it is necessary that the records of diagnosis, treatment, etc. do not allow different interpretations and remain in the original form. Records can only be accessed by a doctor who has one private key and a patient who has another. This information will then only be accessed by those to whom one of these users will provide their private key (for example, the hospital in whole or an individual specialist), etc. 
TABLE I. IMPLEMENTATION OF BLOCKCHAIN IN VARIOUS SPHERES OF LIFE

\begin{tabular}{|c|c|c|}
\hline Industry & Participants & Comments \\
\hline Fashion & $\begin{array}{l}\text { Louis Vuitton and Parfums Dior, it is } \\
\text { possible that other brands from the } \\
\text { LVMH group }\end{array}$ & $\begin{array}{l}\text { Invests in this technology to protect the brand and product quality not } \\
\text { only through lawyers, but through the introduction of digital } \\
\text { technologies }\end{array}$ \\
\hline $\begin{array}{l}\text { Loyalty programs } \text { (banks, } \\
\text { airlines, restaurant networks, } \\
\text { auto business) }\end{array}$ & $\begin{array}{l}\text { Sberbank (banks), Krispay (Singapore } \\
\text { airlines), Chanticleer Holdings (fast } \\
\text { food), HP and Continental (auto), } \\
\text { Boxed (payment companies), etc. }\end{array}$ & $\begin{array}{l}\text { Receiving bonuses, cashbacks requires investment of financial } \\
\text { resources. For example, American companies pay about } \$ 35 \text { billion a } \\
\text { year to maintain such programs. And if bonuses in the form of } \\
\text { cryptocurrency will be credited directly to the client's wallet, the } \\
\text { savings will be very significant. It will be cheaper and easier to } \\
\text { deploy such a system on the blockchain, and this opens the way for } \\
\text { small businesses. }\end{array}$ \\
\hline Tourism & Winding Tree & $\begin{array}{l}\text { They use blockchain technology to unite travel service providers and } \\
\text { sales agents, allowing suppliers to communicate their offers to agents } \\
\text { without intermediaries and their commissions. }\end{array}$ \\
\hline Ecology & $\begin{array}{l}\text { American companies to address issues } \\
\text { with the devastation of groundwater; it } \\
\text { company "Etton Group "(Russia) }\end{array}$ & $\begin{array}{l}\text { Stabilization of groundwater basins in California is solved at the } \\
\text { legislative level, blockchain technologies will be used for trading } \\
\text { underwater waters; development of a system of "Waste Management» }\end{array}$ \\
\hline PR & $\begin{array}{l}\text { Participants - all of the major brand } \\
\text { companies }\end{array}$ & $\begin{array}{l}\text { With the help of blockchain, buyers can find out exactly where a } \\
\text { product was produced or grown or how much workers are paid for } \\
\text { their labor. This is important, especially in an era when consumers } \\
\text { increasingly care not only about the quality of what they buy, but also } \\
\text { about the performance of the company as a whole. }\end{array}$ \\
\hline Labour market & $\begin{array}{l}\text { Personnel Department employees of } \\
\text { all companies }\end{array}$ & Automation, security of personal data storage, resource saving \\
\hline Sport & $\begin{array}{l}\text { Solare is a digital sports asset trading } \\
\text { platform that operates on the Ethereum } \\
\text { blockchain. }\end{array}$ & $\begin{array}{l}\text { The main problem was that the uniqueness and rarity of digital cards } \\
\text { was not confirmed by anything. Sports fans were not eager to give } \\
\text { money for the graphic file placed on the server. The site is a } \\
\text { marketplace where sports geeks can start a collection of football } \\
\text { players ' digital cards. Blockchain solves the main problem - the } \\
\text { uniqueness and limited circulation of each of the cards is fully } \\
\text { confirmed. Another task that the blockchain copes with is the creation } \\
\text { of a favorable environment for sports fans. Last autumn, the Italian } \\
\text { football club "Juventus", announced the release of special tokens. The } \\
\text { blockchain company Socios will help the club to implement the idea. } \\
\text { Juventus Official Fan Token will enable fans to accumulate loyalty } \\
\text { points, receive bonuses, as well as exclusive gifts from Juventus. }\end{array}$ \\
\hline Health & $\begin{array}{l}\text { Czech developers-blockchain } \\
\text { application True Gym }\end{array}$ & $\begin{array}{l}\text { Gradually, the desire to exercise, the analysis of information about } \\
\text { the body and nutrition turns into a whole system, with many } \\
\text { components. And all these components are easy to combine into a } \\
\text { blockchain, }\end{array}$ \\
\hline Logistics & «Delovie linii» & $\begin{array}{l}\text { Previously, control in cargo insurance was carried out on the basis of } \\
\text { paper declarations - this is a classic process. With blockchain, the } \\
\text { process has become much more reliable and faster. Previously, the } \\
\text { loss of a paper contract for insurance could result in losses of } 150-200 \\
\text { million rubles, and now all transactions are recorded and signed } \\
\text { electronically. The system itself generates the necessary declarations. } \\
\text { When the cargo is accepted for transportation, it is insured at the } \\
\text { same second, and all the information in real time replenishes the } \\
\text { database. }\end{array}$ \\
\hline
\end{tabular}

Of course, today Russia lags behind the West in terms of digitalization, but this technology is beginning to be actively used by companies. In Russia, the first to use blockchain technology was the President of Sberbank G. Gref [7]. In foreign companies, these technologies are used more actively and quite successfully. As part of this study, we attempted to assess the degree of implementation of blockchain technology in foreign and Russian companies in various fields of activity (Fig. 1).

The presented analysis shows the scale of the use of blockchain technology in all spheres of human life. However, the presented analysis shows mainly the development of blockchain technology in foreign companies. As already noted by the authors, the blockchain system opens up new competitive opportunities for Russia, but the status of cryptocurrencies still does not have a legislative base, and the government of the Russian Federation is just beginning legislative work in this direction. The beginning of the creation of a revolutionary blockchain platform was initiated by the Central Bank of the Russian Federation in the fall of 2016. «Masterchain» was registered as a trademark six months later.

Today, you can specify a whole galaxy of giants of the domestic market that use blockchain technologies:

- «Sberbank of Russia»;

- Joint Stock Company «ALFA-BANK»;

- Public Joint-Stock Company «Bank Otkritie Financial Corporation»;

- Tinkoff Bank; 
- VTB Bank (Public Joint-Stock Company);

- Gazprombank (Joint Stock Company);

- Vnesheconombank;

- Joint Stock Company Raiffeisenbank;

- MegaFon OJSC;

- PJSC «M.video»;

- S-7 Airlines;

- «Qiwi».

In Russia, b41 Blockchain Development has created Nodes Plus Blockchain -a software platform for industrial solutions based on a distributed registry, the speed of which during load tests exceeded 100 thousand transactions per second (TPS). The scope of application is not limited to industry. Almost any business logic can be implemented on the basis of the platform due to high configurability and innovative features, such as, for example, a server of custom software libraries.

Also, Nodes Plus implements all the functionality inherent in the new generation of blockchains: smart contracts, an arbitrarily controlled consensus mechanism, and more [7]. In 2018, the Federal registration service had registered the first contract of participation in shared construction with the use of blockchain technology [19].

The strategic aspects of this study are that the transition to new technologies will not only increase the country's economic competitiveness on the world stage, but may also further increase its economic security. Strategic reallocation of resources in the field of information development of the company will reduce financial risks. The blockchain technology will occupy a significant part of human life in the near future.

\section{DISCUSSIONS}

Blockchain technologies have many advantages: the rejection of paper media in favor of digital; reduction of intermediaries and creation of products individually for each consumer; increased reliability and security; an increase in the speed of operations and etc. As the analysis shows, the use of these platforms is reflected in various fields from financial to medical, and many foreign universities are beginning to introduce this technology into their educational activities [20-21]. It is especially necessary to note that, despite all these advantages, the implementation and development of the blockchain requires large financial investments. But the need to comply with rapidly changing trends in the macroeconomic market, the growth of digitalization require the introduction of new tools such as blockchain technology. Thus, the transition to blockchain technology as an instrument of the digital economy is already becoming a necessity.

Many leading experts of the cryptocurrency market believe that the current blockchain format can be compared to a steam engine. In their opinion, just as the steam engine once led to the beginning of the world "industrial revolution" - blockchain will lead to a digital revolution. Today, many of them say that the blockchain will finish what the Internet started. Fortunately, the digital revolution is far from over — the evolution continues. Blockchain promises the same decentralized, free and fair situation that the industrial revolution promised centuries ago.

\section{References}

[1] "Strategies for the development of the information society in the Russian Federation for 2017-2030", Decree of the President of the Russian Federation no. 203 of 09.05.2017 [Electronic resource]. Available at: http://kremlin.ru/acts/bank/41919/page/1.

[2] "Digital economy", National project [Electronic resource]. Available at: http://static.government.ru/media/files/3b1AsVA1v 3VziZip5VzAY8RTcLEbdCct.pdf.

[3] Blockchain Congress, 2018 [Electronic resource]. Available at: http://rccongress.ru.

[4] Blockchain-as-a-service companies making the dlt more accessible [Electronic resource]. Available at: https://builtin.com/blockchain/ blockchain-as-a-service-companies.

[5] "The Policy Environment for Blockchain Innovation and Adoption: 2019 OECD Global Blockchain Policy Forum Summary Report”, OECD Blockchain Policy Series, 2019 [Electronic resource]. Available at: www.oecd.org/finance/2019-OECD-GlobalBlockchain-Policy-Forum-Summary-Report.pdf.

[6] D.A. Vladimirskaya and M. Rodionova, "Blockchain as a tool for fighting financial risks", Development of financial relations during the formation of the digital economy, pp. 8-13, 2018.

[7] "Blockchain as part of Russia's digital economy", Real cases [Electronic resource]. Available at: http://marrket.org/publikacii/keysy/blokcheyn-kak-chast-cifrovoyekonomiki-rossii-real-nye-keysy.

[8] Louis Vuitton goes blockchain with AURA [Electronic resource]. Available at: https://vc.ru/trade/82120-louis-vuitton-idet-vblokcheyn-s-aura.

[9] How blockchain will change loyalty programs [Electronic resource]. Available at: https://vc.ru/crypto/78783-kak-blokcheyn-izmenitprogrammy-loyalnosti.

[10] Blockchain on guard of ground water [Electronic resource]. Available at: https://vc.ru/future/71047-blokcheyn-na-strazhegruntovyh-vod.

[11] Branded flavors, automated advertising and blockchain in marketing and advertising [Electronic resource]. Available at: https://vc.ru/marketing/84001-firmennye-aromatyavtomatizirovannaya-reklama-i-blokcheyn-v-marketinge-i-reklame.

[12] As the blockchain is embedded in the healthy lifestyle and sport [Electronic resource]. Available at: https://vc.ru/crypto/63101-kakblokcheyn-vnedryaetsya-v-zozh-i-sport.

[13] Blockchain has reached cargo transportation [Electronic resource]. Available at: https://vc.ru/renins/64716-gruz-v-blockchain.

[14] Blockchain in the automotive industry [Electronic resource]. Available at: https://vc.ru/crypto/59207-blokcheyn-v-avtomobilnoyindustrii.

[15] N. Statsenko, Blockchain and the digital economy [Electronic resource]. Available at: https://rb.ru/story/tokenbox/.

[16] Digital economy in Russia [Electronic resource]. Available at: http://open.gov.ru/events/5516505/.

[17] R. Hackett, IBM and Maersk Are Creating a New Blockchain Company, 16 January 2018.

[18] 12 February 2018, from fortune.com [Electronic resource]. Available at: http://fortune.com/2018/01/16/ibm-blockchain-maerskcompany/.

[19] R.V. Yamshchikov, N.V. Yamshchikova, and D.A. Zakoldaev, "Blockchain technology in Russia: achievements and problems", Bulletin of Moscow Region State University, e-journal, no. 2, 2018 [Electronic resource]. Available at: www.evestnik-mgou.ru.

[20] M.M. Pryanikov and A.V. Chugunov, "Blockchain as a communication basis for the formation of the digital economy: advantages and problems", International Journal of Open Information Technologies, vol. 5, no. 6, 2017 [Electronic resource]. Available at: https://cyberleninka.ru/article/v/blokcheyn-kakkommunikatsionnaya-osnova-formirovaniya-tsifrovoy-ekonomikipreimuschestva-i-problemy.

[21] V.P. Kuznetsova and I.A. Bondarenko, "Blockchain as a tool of digital economy in education", Questions of economic regulation, vol. 9, no. 1, 2018. DOI: 10.17835/2078-5429.2018.9.1.102-109 